\title{
THE CONCEPT OF SELF-DEFENSE IN AMERICAN AND POLISH LEGAL SYSTEMS - A COMPARATIVE ANALYSIS
}

\author{
Katarzyna Ginszt*, Jakub Ginszt*
}

\begin{abstract}
The article is devoted to the issue of self-defense in Polish and American law. Currently, there are attempts to widen the scope of necessary self-protection in Polish legislation and to implement provisions which allow for using greater degree of force by a person attacked at home. The justification of the draft refers to the American law which is more developed in the context of the defense of habitation. Thus, the article provides an analysis of existing legal solutions in American criminal law concerning e.g. the legal definition of self-defense, the use of deadly force, the duty to retreat, the castle doctrine and the provisions which expand this doctrine in comparison with the parallel legal solutions existing in Poland.
\end{abstract}

Key words: self-defense, deadly force, duty to retreat, castle doctrine, defense of habitation

\section{INTRODUCTION}

For most Europeans the United States is the country of a great legal potential where the state respects almost-absolute rights of individuals. It is also given as an example of well-functioning legal system. Such a tendency is also visible among Polish citizens who often refer to the concepts of e.g.

*MA, ka.ginszt@gmail.com.

** MA, trainee legal advisor, ginszt@gmail.com. 
autonomy of the will, the right to bear arms or the right to resources under your land as the synonyms of American-style respect for its inhabitants. Such opinions are explicitly visible in the context of propositions of legal changes concerning the extension of self-defense provision in Polish Penal Code. Currently, the Minister of Justice has created a draft amendment to the Penal Code, according to which „anyone who exceeds the limits of necessary self-defense, responding to an attack involving unlawful entry into a dwelling, premises, a house or a fenced area connected to them or responding to an attack proceeded by an unlawful entry to such places, is not subject to penalty, unless the exceeding of self-defense is blatant" ${ }^{\text {. In }}$ the justification of the draft there is a reference to the American criminal law. The justification states that in the US a defender can take action when he or she responds to an attack on his or her life, health, freedom as well as property and when this attack involves force or intrusion. Moreover, it is highlighted that Anglo-Saxon legal systems draw special attention to the concept of the defense of habitation ${ }^{2}$.

In view of proposed legal changes in Poland and the clear reference to the US legislation, making a comparison of Polish concept of self-defense to the American one is something more than natural. Accordingly, it is worth to make an analysis of Polish and American criminal law and existing legal solutions concerning self-protection, especially using self-defense force when attacked at home.

${ }^{1}$ The draft of 9 June 2017 of Act amending the Act - the Penal Code, published on the Ministry of Justice of the Republic of Poland official website: http://legislacja.rcl.gov.pl/ docs//2/12299357/12439161/12439162/dokument293450.pdf. It is worth remembering, that in year 2007 and 2015 there was an attempt to introduce similar regulation: The draft of 18 May 2007 of Act amending the Act - the Penal Code and certain other acts, printed matter no. 1756, published on the Parliament of Poland official website: http://orka.sejm. gov.pl/Druki5ka.nsf/0/C1CA93E0F503AF82C12572EC00267570/\$file/1756.pdf

The draft of 19 January 2015 of Act amending the Acet -the Penal Code, printed matter no. 3224, published on the Parliament of Poland official website: http://orka.sejm. gov.pl/Druki7ka.nsf/0/F58AA8DAEECA0068C1257E06002C906F/\%24File/3224.pdf

${ }^{2}$ The draft of 9 June 2017, 4-5. 


\section{Common law}

Derived from two different legal cultures, the American and Polish law can be difficult to compare. The US law has its roots in the English common law which was adopted when the newcomers colonialized America. However, since the beginning, the application of English precedents has been depended on decisions of American judiciary. Although reception was implemented in different states individually, and the laws were interpreted differently according to the local conditions of a state, it provided a basis for the American legal system, such as e.g. the power of courts to develop laws ${ }^{3}$. Today, when it comes to the criminal law, the law-making function has been generally shifted to legislatures as the majority of states created criminal codes. It is worth remembering that the US Constitution grants the power of formulating criminal law to individual states and the federal level of jurisdiction deals only with federal offences ${ }^{4}$. In developing criminal codes the Model Penal Code played an indispensable role. Drafted by the American Law Institute in 1962 and finally updated in 1985, the document constituted a basis for creating and changing the criminal codes in nearly three-quarters of the American states ${ }^{5}$. Therefore, when analyzing the concept of self-defense all of the above-mentioned aspects have to be taken into consideration.

\section{Continental law}

Continental law existing in Poland is governed by different rules and has different origins than the American common law. The main feature is codification of the law through legislation and a clear separation of leg-

${ }^{3}$ Stanisław Pomorski, "American Common Law and the Principle Nullum Crimen Sine Lege", Warszawa: PWN, 1975, pp. 33-35.

${ }^{4}$ Markus Dirk Dubber, Kevin Jon Heller, “The Handbook of Comparative Criminal Law”, Stanford, Calif: Stanford Law Books, 2011, pp. 564-565.

5 Dubber, Heller, "The Handbook of Comparative Criminal Law", p. 565. 
islative and judicial powers ${ }^{6}$. Unlike in common legal system, continental law does not evolve when a court decision is made. However, there is a growing tendency to use the existing judicature as a point of reference and a guideline for the courts. Codification of law attempts to provide provisions for all matters that could be brought in the legal process in different categories of law. In Poland, in the field of criminal, material law, the Penal Code is a fundamental document. It establishes crimes as well as appropriate penalties. Codification of crimes in codes and acts is connected with the article 42 of the Constitution of the Republic of Poland (1997), which establishes the nullum crimen sine lege rule. According to this article "only a person who commits an act punishable under the law in force at that time bears criminal liability". Moreover, Poland is obliged to respect international documents, especially those resulting from Polish membership in European organizations ${ }^{7}$.

\section{LEGAL DEFINITIONS OF SELF-DEFENSE}

\section{Self-defense in the US}

The use of force in self-defense in the US is described in Section 3.04 of the Model Penal Code. Self-protection or "Use of Force Justifiable for Protection of the Person" is described as follows: “(...) the use of force upon or toward another person is justifiable when the actor believes that such force is immediately necessary for the purpose of protecting himself against the use of unlawful force by such other person on the present occasion" ${ }^{8}$. In other words a person can use physical force when he or she

${ }^{6}$ John Henry Merryman, Rogelio Perez-Perdomo, „The Civil Law Tradition - an Introduction to the Legal Systems of Europe and Latin America“, Stanford California: Stanford University Press, 2007, p. 30.

${ }^{7}$ Above all, in the context of self-defense the Covention for the Protection of Human Rights and Fundamental Freedom from 4th November 1950 (Journal of Laws of 1993 No 61 item 284) is a crucial document.

${ }^{8}$ American Law Institute. Model Penal Code: Official Draft and Explanatory Notes: Complete Text of Model Penal Code as Adopted at the 1962 Annual Meeting of the Amer- 
has an honest believe that this force is essential to protect oneself against the imminent threat of an unlawful use of force.

\section{Self-defense in Poland}

In Polish legal system, self-defense is defined in art. $25 \$ 1$ of the Penal Code ${ }^{9}$, according to which: ,anyone who, out of necessary self-defense, repels a direct illegal attack on any legally protected interest is not deemed to have committed an offence". In other words, conducts which normally would be recognized as crimes are not illegal when their purpose is a protection against an unlawful use of force. The definition refers to protection of all interests by the law. Thus, the use of force in protection of: oneself, other persons and other interests like property or social goods, e.g. public order and safety, does not fall into a category of a crime ${ }^{10}$. In American law, the use of force in order to protect other persons and interests is also justifiable, however, it is described separately in different sections of the Model Penal Code (sec. 3.05, sec. 3.06). It should be stated at this point that the article is devoted mainly to the use of force in self-protection.

\section{THE PRINCIPAL ELEMENTS OF SELF-DEFENSE}

A perfect self-defense in the US

Under the MPC as well as under the common law four elements have to occur for a person to be fully protected by the self-defense doctrine and to claim a perfect self-defense, which provides complete exoneration for the defendant ${ }^{11}$. Firstly, the attack or a threat of attack must occur. The

ican Law Institute at Washington, D.C., May 24, 1962. Philadelphia, Pa.: The Institute, 1985.

${ }^{9}$ Act of 6 June 1997 - the Penal Code, Journal of laws 1997 No. 88, item 553, as amended

${ }^{10}$ Magdalena Błaszczyk and others, "Kodeks Karny Część Ogólna”, ed. Michał Królikowski, Robert Zawłocki, Warszawa: C.H. Beck, 2017.

${ }^{11}$ Stephen Michael, Ian Kunen, "Superhuman in the Octagon, Imperfect in the Courtroom; Assessing the Culpability of Martial Artists who killed during Street Fights", Emory Law Journal. 6(2011): 1399. 
self-defense doctrine applies only if a person responds, not when he or she is the initial attacker. For the response to be justifiable the aggressor's force has to be unlawful ${ }^{12}$. The situation becomes more complex when it refers to actions of public authorities. Here arises a question whether it is justifiable to resist an unlawful arrest made by a peace officer. According to the Model Penal Code: "[ $t]$ he use of force is not justifiable [...] to resist an arrest that the actor knows is being made by a peace officer, although the arrest is unlawful". The majority of states incline towards the MPC's view ${ }^{13}$, although there are still some states which allow their citizens to resist an illegal arrest ${ }^{14}$. Secondly, the claim of self-defense can be used only when the threat is imminent and the attack is forthcoming. The threatening situation only limits to the present as the self-defense doctrine do not apply to prevent against future attacks or revenge. These two abovementioned aspects refer to the nature of the attack ${ }^{15}$.

The next two characteristics correspond to the elements of the response. Both the MPC and the common law require the proportionality of force used in defense with reference to the threat. A reasonable amount of force, which is proportional to the harm that threatens, should be used. The MPC provides justifications for the use of deadly force, which are: protection "against death, serious bodily injury, kidnapping or sexual intercourse compelled by force or threat" (MPC sec. 3.04 Explanatory Notes). A reasonable balance between the use of non-deadly force or deadly force against the attacker and the threatened harm has to be sustained.

The second aspect, which has to be considered, is the defender's subjective or objective belief that the use of force is necessary ${ }^{16}$. According to the

${ }^{12}$ Michael, Kunen, „Superhuman in the Octagon.”, p. 1396.

${ }^{13}$ Andrew P. Wright, "Resisting Unlawful Arrests: Inviting Anarchy or Protecting Individual Freedom?”, Drake Law Review 2(1997): 387-88. August 25, 2017 https://lawreviewdrake.files.wordpress.com/2016/09/wright.pdf.

Darrell A. H. Miller, „Retail Rebellion and the Second Amendment“, Indiana Law Review 3(2011): 953. August 25, 2017 http://www.repository.law.indiana.edu/ilj/vol86/iss3/5.

${ }^{14}$ In Indiana, according to Indiana Code, Title 35 „Criminal Law and Procedure” $\$$ 35-41-3-2: „(i) A person is justified in using reasonable force against a public servant if the person reasonably believes the force is necessary to:(1) protect the person or a third person from what the person reasonably believes to be the imminent use of unlawful force; (...)".

${ }^{15}$ Michael, Kunen, „Superhuman in the Octagon.”, p. 1397.

${ }^{16}$ Michael, Kunen, „Superhuman in the Octagon.”, p. 1397. 
Model Penal Code to support the defense a subjective belief is enough. The situation is examined from the point of view of a particular actor and his or her own assessment of the situation. On the other hand, it is more common to apply an objective standard ${ }^{17}$. The United States Supreme Court in Beard v. United States (1895) stated that along with a personal honest belief a reasonable standard must be met ${ }^{18}$. The standard of a reasonable person determines what action a person with ordinary intelligence and prudence would have taken if he or she had been in the same position as the actor ${ }^{19}$. The US criminal law often requires employing a reasonable person test. It involves a series of questions which should be answered affirmatively. "[I] $\mathrm{t}$ is conventional to ask whether the actor believes, and whether a reasonable person would believe, each of the following facts: (a) an aggressor was threatening him with harm, (b) that harm would be of a particular level of gravity, (c) his use of force in response would prevent that harm, (d) the level of responsive force he expects to employ would be of a similar level of gravity, (e) if the force was not used, the threatened harm would occur immediately, and (f) no nonviolent or less forceful alternatives were available whereby the threat could be avoided" 20 . The questions are answered from the point of view of a reasonable person.

\section{Elements of self-defense in Poland}

Similarly to the American law, in Polish law the principle elements of self-defense can also be divided into two categories, i.e. the elements of

${ }^{17}$ Paul C., Giannelli, „Self Defense”, Faculty Publications 2(1988): 409. July 17, 2017 http://scholarlycommons.law.case.edu/faculty_publications/409.

${ }^{18}$ Beard v. United States 158, U.S. 550 (U.S. Supreme Court 1895) „(...) the question for the jury was whether, without fleeing from his adversary, he had at the moment he struck the deceased, reasonable grounds to believe, and in good faith believed, that he could not save his life or protect himself from great bodily harm except by doing what he $\operatorname{did}(\ldots)$ ".

${ }^{19}$ Mark R. Hinkston, „Home Safe Home: Wisconsin's Castle Doctrine and Trespasser Liability”, Wisconsin Lawyer 5(2013). July 21, 2017 http://www.wisbar.org/newspublications $/$ wisconsinlawyer $/$ pages $/$ article aspx? volume $=86 \&$ issue $=5$ \&articleid $=10836$.

${ }^{20}$ Kenneth W. Simons, „Self-Defense: Reasonable Beliefs or Reasonable Self-Control?”, New Criminal Law Review, 1 (2008): 51-90. 
the attack and the elements of the response ${ }^{21}$. The basic premise, which falls into the first group, is the mere existence of the attack which can be defined as dangerous behavior of another person that infringes or is about to infringe a legal interest ${ }^{22}$. The attack has to be real - exist objectively. The sole belief of an actor that the threat is real is not enough for the response to be classified as a self-defense act $^{23},{ }^{24}$. Moreover, the attack should be unlawful, i.e. contrary to the existing law, whereas it is of no significance if the attack infringes regulations of a penal, civil or administrative code. A contrario, self-defense cannot be applied against action taken in accordance with the law, e.g. by peace officers, however, similarly to the American law, this rule is not of absolute character. Thus, when a peace officer acts without any legal basis or his/her actions go beyond the scope of authority, his/her behavior will be recognized as unlawful and will justify the use of self-defense against $i^{25}$. Unjustified use of violence would be an example of such behavior ${ }^{26}$. However, if public authorities act within the law and their competences, then the actions performed by them are legal and the response to those actions does not fall under self-protection, even when they are materially incorrect ${ }^{27}$, e.g. an arrest of a wrong person ${ }^{28}$.

${ }^{21}$ Zbigniew Jędrzejewski, and others, "Kodeks Karny. Komentarz 2016”, ed. Lech Paprzycki, Legalis.

${ }^{22}$ Paweł Daniluk, “Kodeks Karny. Komentarz 2016”, ed. Ryszard Stefański, Legalis.

${ }^{23}$ Roman Góral, "Obrona konieczna w praktyce”, Warszawa: Europejska Wyższa Szkoła Prawa i Administracji, 2011, p. 38.

${ }^{24}$ However, if a mistake in judgement is justified, the use of force by a defender would not be a crime according to art. 29 of the Penal Code.

25 (see also a decision of Polish Supreme Court [SN of 2 December 1972., Rw 1236/72, unpub.)

${ }^{26}$ Andrzej Zoll, "Kodeks Karny. Komentarz, część ogólna”, Kraków: Zakamycze 2004, p. 473.

${ }^{27}$ Also court's decision from ECHR of 17 March 2005 in Bubbins v. United Kingdon, application no. 50196/99, reads that the use of weapon by public officers "may be justified when it is based on an honest belief which is perceived, for good reasons, to be valid at the time but subsequently turns out to be mistaken".

${ }^{28}$ Lech Gardocki, "Prawo karne", Warszawa: C. H. Beck, 1998, p. 110; There is also a view according to which the use of self-defensive force is justified against materially wrong actions when such actions can lead to irreversible harm. 
Secondly, the attack should be direct, which means that it has begun or there is high probability it will begin shortly ${ }^{29}$. Acting in self-protection would not be possible if the realization of an attack has not even entered its initial stage yet ${ }^{30}$ or when a defender is no longer under threat.

The two other elements characteristic for the response are: necessity and commensuration. Although these two aspects seem to be similar, they need to be assessed individually. Necessity concerns the need for defense whereas commensuration refers to the proportionality of the response to danger ${ }^{31}$.

When it comes to necessity, the use of protective force is not an obligation but it is an entitlement, therefore, an attacked person can but do not have to respond. Another matter concerns the use of self-protection when there are other means possible to avoid the attack. This issue is described thereinafter.

Commensuration of defense does not mean that the response has to be identical to the attack. Quite the contrary, as a person under attack is entitled to apply effective defense, gaining advantage over an attacker is needed. Judicature indicates that "the defensive action of a person who acts in self-protection should exceed in its intensity the intensity of the attack" 32 . In addition, proportionality between legal interests of an attacker and defender is generally required i.e. the value of legal interest which is infringed by a defender should not be far more valuable than the interest protected $^{33}$. This matter is raised in article 2 of the European Convention on Human Rights, according to which everyone's right to life shall be protected by law. As the paragraph 2 states: „, [d] epravation of life shall not be regarded as inflicted in contravention of this article when it results from

${ }^{29}$ Andrzej Marek, „Obrona konieczna w prawie karnym. Teoria i orzecznictwo”, Warszawa: Wolters Kluwer, 2008, pp. 58-59.

${ }^{30}$ decision of Polish Supreme Court [SN of 23 April 1974 IV KR 38/75, (OSNKW 1974) no. 9 item 165].

${ }^{31}$ Andrzej Marek, „Obrona konieczna”, p. 90.

${ }^{32}$ A decision of Polish Supreme Court [SN of 14 June 1984 1KR 123/84 Legalis], decision of Polish Supreme Court [SN of 10 January 1969 4KR 234/68, Legalis].

${ }^{33}$ Andrzej Marek, „Obrona Konieczna”, p. 130; Andrzej Zoll, „Kodeks Karny”, p. 416 . 
the use of force which is no more than absolute necessary: a. in defense of any person from unlawful violence“.

\section{BREACHING THE LIMITS OF SELF-DEFENSE}

An imperfect self-defense in the US

Some jurisdictions recognize a partial defense of a person who used a deadly force against the attacker when the force was unjustified from the legal perspective. The doctrine of an imperfect self-defense can mitigate liability for defendant's actions. According to the MPC, when a defender makes a mistake in his/her belief or he/she forms his/her belief recklessly or negligently regarding the use of force in self-defense, "he[/she] cannot be prosecuted for an offense that requires purpose to establish culpability" (MPC sec. 3.04 Explanatory Note). However, such person can be held responsible for an offense of recklessness or negligence ${ }^{34}$. Thus, when the belief was honest but mistaken a person cannot be held liable for intentional homicide as there is no aspect of malice. Instead, a defender can be prosecuted for e.g. manslaughter ${ }^{35}$. The doctrine of an imperfect selfdefense mitigates the crime but does not exonerate a defendant.

\section{The excess of self-defense in Polish law}

Polish criminal law includes regulations concerning liability mitigation in case the response to a threat or an attack is incorrect. According to art. 25 par. 2 of Polish Penal Code, "[i]f the self-defense exceeds what is necessary, in particular when the offender uses a means of defense disproportionate to the danger of the attack, the court may apply an extraordinary mitigation of the penalty, or even issue an absolute decree". There are two types of exceeding the limits of necessary defense. The first one, described in the article above, is defined as intensive excess and concerns

\footnotetext{
${ }^{34}$ See sec. 3.09 of the Model Penal Code.

${ }^{35}$ Giannelli, ,Self Defense”, p. 409.
} 
the use of defensive force which is not proportional to a threat of harm. The second type, called extensive excess, involves using defensive force before the threat of an attack has started or after the threat has ended. In both cases, the response would constitute a crime, however, with a possibility to mitigate criminal liability. Moreover, according to art. 25, par 3. of the Penal Code: „[a] person who exceeds the limits of necessary self-defense as a result of fear or emotional distress justified by the circumstances of the attack in not subject to a penalty".

Furthermore, if a mistake in judgment of the use of defensive force has been made and a defender infringed legal interest of another person, according to art. 29 of the Penal Code "no offence is committed by anyone who performs a prohibited act in the justified but mistaken conviction that there are circumstances excluding unlawfulness or guilt; if the offender's mistake is unjustified, the court may apply an extraordinary mitigation of the penalty".

\section{FIGHT OR FLIGHT?}

\section{Duty to retreat in American law}

Self-defense may sometimes require taking attacker's life. The use of deadly force in self-defense in American law has been limited by the duty to retreat. This doctrine has its roots in English common law which stated that a defender had to "put his back against the wall" before killing the wrongdoer in self-defense. Americans had questioned the concept since the $19^{\text {th }}$ century as some courts, e.g. in Ohio, found it disgracing to retreat rather than fight (the true man doctrine) in Erwin v. State $(1876)^{36}$. In Indiana the duty to retreat was also repudiated. In Runyan v. State (1877)

${ }^{36}$ Erwin v. State (No. 29) (1876), Ohio St. 186, 199, "The law, out of tenderness for human life and the frailty of human nature, will not permit the taking of it to repel mere trespass, or even to save a life where the assault is provoked; but a true man who is without fault is not obliged to fly from an assailant, who by violence of surprise maliciously seeks to take his life or do him enormous bodily harm". 
the Supreme Court addresses the "American mind" argument ${ }^{37}$. On the other hand, some states stick to the rule claiming that it is more distasteful to kill than to retreat ${ }^{38}$. Today, at least 24 states implemented no duty to retreat laws ${ }^{39}$. The MPC also provides for circumstances that eliminate the duty to retreat which include the attack at a defender's home or a place of work.

\section{Autonomy and subsidiarity of self-defense in Polish law}

The issue of avoiding harm in other ways than the use of defensive force by an attacked person has also been raised in Poland. The views presented in doctrine are contradictory.

According to the first one, the legal right to self-defense is an autonomous right, which means that the mere attack itself justifies repelling it by force. An attacked person is entitled to use defensive force without the need for retreating, hiding, avoiding the confrontation or calling public authorities for help. Self-defense is a protection of law against unlawfulness ${ }^{40}$. Furthermore, the concept of self-defense stems from a natural pro-

${ }^{37}$ Runyan v. State, (No.57) (1877) Ind. 80, 84, „A very brief examination of the American authorities makes it evident that the ancient doctrine, as to the duty of a person assailed to retreat as far as he can, before he is justified in repelling force by force, has been greatly modified in this country, and has with us a much narrower application than formerly. Indeed, the tendency of the American mind seems to be very strongly against the enforcement of any rule which requires a person to flee when assailed, to avoid chastisement or even to save human life, and that tendency is well illustrated by the recent decisions of our courts, bearing on general subject of the self-defense."

38 Steven P. Aggergaard, "Criminal Law - Retreat from Reason: How Minnesota's New No-Retreat Rule Confuses the Law and Cries for Alteration - State v. Glowacki”, William Mitchell Law Review 2 (2002): 662-665.

${ }^{39}$ Alabama (AL Code $\$ 13 \mathrm{~A}-3-23$ ), Alaska (AS $\$ 11.81 .335$ ), Arizona (A.R.S. $2017 \$$ 13 - 405), Florida (FS 776.012), Georgia (O.C.G.A. \$ 16-3-23.1), Indiana (IC \$35-41-32), Kansas (K.S.A \$ 21-5230), Kentucky (KRS 503.055), Louisiana (LA RS 14:19), Michigan (ML 780.972), Mississippi (MS Code $\$ 97-3-15)$, Montana (MCA 45-3-110), Nevada (NRS 200.120), New Hampshire (NHS 627:4), North Carolina (NCS \$ 14-51.3), Ohio (ORC \$ 2901.09), Oklahoma (OKC 21-1289.25), Pennsylvania (PAC \$ 505), South Carolina (SCC 16-11-440), South Dakota (SDC 22-18-4), Tennessee (TC 22-18-4), Texas (TPC \$ 9.31), Utah (UC 76-2-402), West Virginia (WVC \$55-7-22).

${ }^{40}$ An order of the Polish Supreme Court of 16 November 2009 IV 105/09. 
tective instinct and has its source in the natural law and constitutional norms. The duty to retreat is contradictory to the right of staying unrestrictedly in a place where has a legal right to be guaranteed by the state. Such a view on the matter dominates in doctrine and is widely accepted ${ }^{41}$. The second view, which is highly criticized, presents subsidiary character of self-defense, i.e. responding is allowed only when there is no other means at all to avoid attack. There is also a view that falls in between the two presented above which states that self-defense has relatively subsidiary character. Applying self-protection depends on common sense and logic assessment of the situation. According to this view "repelling an attack by an infringement of attacker's interest is justifiable only when there is no other rational way of avoiding it" ${ }^{\star 2}$.

\section{DEFENSE OF HABITATION}

\section{Castle doctrine, stand your ground law, make my day law}

The doctrine owes its name to an old English expression that "a man's home is his castle". This comparison immediately brings connotation of safety, respect and significant importance of a place where one lives. Consequently, the castle doctrine recognizes home as a place of special legal treatment in a context of self-defense. Many states have adopted "castle doctrine" bills which entitle a defender to use deadly force without retreating in more circumstances as well as which grant legal immunity, both civil and criminal, to those who legally use force against the attacker. However, different states adopted different provisions. In Alaska, the castle doctrine expands on other premises and no-duty-to-retreat is applied not only to a place of residence but also to e.g. a place of work, a place one leases or a place where a person is a guest ${ }^{43}$. Kansas, on the other hand, allows for

${ }^{41}$ Roman Góral, „Obrona konieczna”, 25. and titles mentioned there.

${ }^{42}$ Andrzej Zoll, „Kodeks Karny. Komentarz”, Warszawa: Wolters Kluwer, 2007, p. 415 .

${ }^{43}$ AS 11.81.335. Justification: Use of Deadly Force in Defense of Self. 
a use of force in self-defense and does not require defenders to retreat at any property a person legally possesses ${ }^{44}$. Florida adds provisions which make a presumption that a person could have reasonably feared death or serious bodily harm when an intruder illegally entered or was trying to enter a place of dwelling or an occupied car. Also, intruder's actions are presumed to be taken with criminal intent and are presumed to involve force or violence ${ }^{45}$. Some bills recognize defenders as immune from criminal prosecution, which "can apply to arrest, detention in custody, charging and prosecuting" ${ }^{46}$. Some states follow standard procedures but a person cannot be arrested except if the defensive force is suspected to have been used illegally. Moreover, many states grant civil immunity as well.

The circumstances of justifiable homicide under the principle of the castle doctrine has been redefined and effectively expanded by stand your ground and make my day laws. Stand your ground law has been introduced by nineteen states: Alabama, Arizona, Florida, Georgia, Indiana, Kansas, Kentucky, Louisiana, Michigan, Mississippi, Montana, New Hampshire, Oklahoma, South Carolina, South Dakota, Tennessee, Texas, Utah and West Virginia ${ }^{47}$. It generally gives the right to use a defensive force, including deadly force, against the attacker in venues outside home and, furthermore, grants legal immunity to those who defend themselves in any place they have a legal right to be ${ }^{48}$. The possibility to defend oneself wherever a person is and with whatever means necessary has many supporters, together with the National Riffle Association. They believe the statues allow law-abiding citizens to protect themselves against unlawful

${ }^{44}$ K.S.A. 2011 Supp. $\$ \$ 21-5220$ through 21-5231 (Kansas' Self-defense \& Defense of others Statutes).

${ }^{45}$ Committee Substitute for Senate Bill No. 436 chapter 2005-27, Florida SB-436, "Castle Doctrine".

${ }^{46}$ Christopher Reinhart, "Castle Doctrine and Self-defense", Connecticut General Assembly, Office of Legislative Research (2007). 27 August 2017 https://www.cga. ct.gov/2007/rpt/2007-r-0052.htm.

${ }^{47}$ Chandler McClellan, Erdal Tekin, "Stand Your Ground Laws, Homicides, and Injuries.” Journal of Human Resources, 3(2017): 628-629. EBSCOhost, DOI:10.3368/ jhr.52.3.0613-5723R2.

${ }^{48}$ Marc Guis, „The Relationship between Stand-Your-Ground Laws and Crime: A State-Level Analysis" The Social Science Journal 3(2016): 329-338. DOI: 10.1016/j. soscij.2016.01.001. 
attack. On the other hand, there is also a criticism concerning the laws. Opponents claim that stand-your-ground provisions lead to escalation of violence on the streets and constitute a convenient excuse for people who intentionally commit crime ${ }^{49}$. One of the most controversial cases was a case of State of Florida v. Zimmermann. On 26th February 2012 George Zimmerman was driving his car when he saw Trayvon Martin - a 17-teenyear-old Afro-American. In the context of numerous burglaries and thefts that had happened in the neighborhood recently, Zimmerman suspected the young man to be a criminal and called the non-emergency police number. Without waiting for an officer to arrive, Zimmerman followed Martin who, being afraid of a man following him, started to run home. Zimmerman, falsely assuming that a criminal was running away, confronted young boy. A fight started which led to shooting an unarmed Martin dead. Zimmerman was charged with a second-degree murder. The defense claimed self-defense on the grounds of stand-your-ground law and the jury found the defendant not guilty on $13^{\text {th }}$ July 2013. According to Florida Statues: "A person is justified in using or threatening to use deadly force if he or she reasonably believes that using or threatening to use such force is necessary to prevent imminent death or great bodily harm to himself or herself or another or to prevent the imminent commission of a forcible felony. A person who uses or threatens to use deadly force in accordance with this subsection does not have a duty to retreat and has the right to stand his or her ground if the person using or threatening to use the deadly force is not engaged in a criminal activity and is in a place where he or she has a right to be" 50 .

Another law that goes beyond the castle doctrine is called make my day law. For the first time enacted in Colorado in 1985, make my day legislation gives possibility to state courts to "presume self-defense" whenever

49 Chandler McClellan, Erdal Tekin, "Stand Your Ground Laws”, p. 625.

${ }^{50} 2017$ Florida Statues 776.012 Use or threatened use of force in defense of person; at the time of a trial 2012 Florida statues 776.013 was as follows: "(3) A person who is not engaged in an unlawful activity and who is attacked in any other place where he or she has a right to be has no duty to retreat and has the right to stand his or her ground and meet force with force, including deadly force if he or she reasonably believes it is necessary to do so to prevent death or great bodily harm to himself or herself or another or to prevent the commission of a forcible felony." 
a homeowner uses deadly physical force against an intruder ${ }^{51}$. With an attempt to grant an absolute safety to its citizens in their homes ${ }^{52}$, Colorado legislatures allow defenders to kill trespassers as long as they believe the intruders have criminal intent and may use physical force, "no matter how slight" ${ }^{3}$. The judicature concerning the self-defense cases shows the tendency to expand the self-defense even further. Ruben Martinez did not face chargers when on $2^{\text {nd }}$ September 2016 he killed his roommate Tarchan Silcott. There was an argument between the two young men and when Martinez locked himself in his room. Silcott broke down the doors and attacked his friend. In response Martinez fatally stabbed Silcott. The case was not a usual intruder's case but still Silcott forced the Marinez's bedroom door open with an intend to cause him harm. Therefore, under the make my day statutes there was no criminal liability in this case.

\section{Self-defense at home - proposition of changes in Polish Penal Code}

Currently, there is no distinction between self-protection at home and other venues. According to the Polish law, an attacked person can defend oneself in any place a person has a legal right to be, but the use of force need to be proportional. For the defense to be effective, the force used by a defender should be greater than the force used by an attacker, however, the condition of proportionality imposes an obligation to choose mean of

${ }^{51}$ Blodgett, Nancy. " 'Make my day': Open season on intruders." ABA Journal, 6(1985): 20.

52 The 18-1-704.5 Use Of Deadly Physical Force Against An Intruder ("Make My Day Law") Colorado Statutes Regarding Deadly Physical Force and Carrying Concealed Weapons reads: "The general assembly hereby recognizes that the citizens of Colorado have a right to expect absolute safety within their own homes."

${ }^{53}$ CS18-1-704.5: "Notwithstanding the provisions of section 18-1-704, any occupant of a dwelling is justified in using any degree of physical force, including deadly physical force, against another person when that other person has made an unlawful entry into the dwelling, and when the occupant has a reasonable belief that such other person has committed a crime in the dwelling in addition to the uninvited entry, or is committing or intends to commit a crime against a person or property in addition to the uninvited entry, and when the occupant reasonably believes that such other person might use any physical force, no matter how slight, against any occupant." 
protection which is the least harmful among the equally effective means of protection.

The proposed changes entitle homeowners to use protective force which is disproportional but the disproportion should not be blatant. According to the amendment, a defender would not be a subject to penalty in such a case. The draft provides justification that "special circumstances of the attack, i.e. intrusion into a dwelling and significant invasion of privacy, which constitute a major social danger, justify using any means to repel the attacker and the attack. Thus, a person using a defensive force should not be subject to penalty even if he or she exceeds the limits of necessary self-defense."

Similar drafts were proposed and rejected in the past. The criticism of the earlier drafts pointed out that there already was an article 25 par. 3 of the Penal Code which could be applied to protect defendant against punishment when he or she had exceeded the limits of self-defense ${ }^{54}$. According to this article, which is still in force, a blatant excess of defensive force is justifiable when a person used it as a result of strong emotional reaction experienced because of the circumstances of the attack. Intrusion into a dwelling can certainly be recognized as a situation in which a person feels fear and emotional distress, thus, this article and the proposed one overlap.

Moreover, it was raised in criticism that the update of the law could be contradictory to the art. 2 par 2 of ECHR, according to which taking somebody's life in self-defense is only possible when it is absolutely necessary ${ }^{55}$.

${ }^{54}$ An opinion of the Attorney General of Poland from 25 November 2014, published on the Parliament of Poland official website: http://orka.sejm.gov.pl/Druki7ka.nsf/0/46D78D85997B55BDC1257DA300380B02/\%24File/2971.pdf.

Martyna Sepko, „Rozważania na temat propozycji rozszerzenia granic obrony koniecznej w projekcie poselskim z 19 stycznia 2015 r.", Internetowy Przegląd Prawniczy TBPS UJ, 1(2015). September 1, 2017 http://www.tbsp.wpia.uj.edu.pl/documents/4137545/ d24eb2da-09ae-4708-b8e1-d4338c074306.

${ }^{55}$ An opinion of the Attorney General of Poland from 25 November 2014. 


\section{CONCLUSION}

The comparative analysis shows that despite the fact that the American and Polish laws are derived from different legal traditions, some similarities between them can be noticed, especially those concerning the distinguished elements of self-defense. Furthermore, in both countries there is no criminal liability attached to the proper use of self-protection, which means that a person who uses defensive force to repel an attack does not commit a crime. Also, analogous problems arise when the self-defense is used against e.g. public authorities or when self-protection leads to the death of an attacker. In both countries different views are presented on the issue of confrontation when retreat is possible. The analysis shows as well that in Poland and in the US there is a tendency and there are attempts to widen the scope of necessary self-defense. In states which has implemented provisions like stand your ground or make my day laws, the possibility to defend oneself against an unlawful attack is much greater than in Poland. Such legal solutions certainly attempt to protect law-abiding citizens, however, they can also lead to the abuse of law. On the other hand, there are also states which still have the duty to retreat provisions which in Poland - according to the prevailing view - does not exist.

\section{REFERENCES:}

Aggergaard, Steven P. 2002. "Criminal Law - Retreat from Reason: How Minnesota's New No-Retreat Rule Confuses the Law and Cries for Alteration - State v. Glowacki”, William Mitchell Law Review 29(2): 657-693.

Blodgett, Nancy. 1985. " 'Make my day': Open season on intruders." Colorado: ABA Journal 71(6): 20.

Błaszczyk Magdalena, and others. 2017. "Kodeks Karny Część Ogólna”, ed. Michał Królikowski, Robert Zawłocki, Warszawa: C.H. Beck.

Daniluk, Paweł. 2016. “Kodeks Karny. Komentarz 2016”. ed. Ryszard Stefański. Legalis.

Dubber, Markus Dirk, Kevin Jon Heller. 2011. "The Handbook of Comparative Criminal Law”. Stanford, Calif: Stanford Law Books. 
Gardocki, Lech. 1998. "Prawo karne”. Warszawa: C. H. Beck.

Giannelli, Paul .C. 1988. "Self Defense”, Faculty Publications 18(2): 1-8. July 17, $2017 \mathrm{http}: / /$ scholarlycommons.law.case.edu/faculty_publications/409

Góral, Roman. 2011. "Obrona konieczna w praktyce". Warszawa: Europejska Wyższa Szkoła Prawa i Administracji.

Guis, Marc. 2016. „The Relationship between Stand-Your-Ground Laws and Crime: A State-Level Analysis". The Social Science Journal 53(3): 329-338. DOI: 10.1016/j.soscij.2016.01.001.

Hinkston, Mark R. 2013. „Home Safe Home: Wisconsin’s Castle Doctrine and Trespasser Liability”, Wisconsin Lawyer 86(5). July 21, 2017 http://www.wisbar.org/newspublications/wisconsinlawyer/pages/article. aspx? volume $=86 \&$ issue $=5 \&$ articleid $=10836$.

Jędrzejewski, Zbigniew, and others. 2016. "Kodeks Karny. Komentarz 2016”, ed. Lech Paprzycki. Legalis.

McClellan, Chandler, Erdal Tekin. 2007. "Stand Your Ground Laws, Homicides, and Injuries." Journal of Human Resources. 52(3) 621-653. EBSCOhost, DOI:10.3368/jhr.52.3.0613-5723R2.

Merryman, John Henry, Rogelio Perez-Perdomo. 2007. „The Civil Law Tradition - an Introduction to the Legal Systems of Europe and Latin America“. Stanford California: Stanford University Press.

Michael, Stephen, Ian Kunen. 2011. „Superhuman in the Octagon, Imperfect in the Courtroom; Assessing the Culpability of Martial Artists who killed during Street Fights". Emory Law Journal. 60(6): 1390-1435.

Miller, Darrell A. H. 2011. „Retail Rebellion and the Second Amendment“, Indiana Law Review 86(3): 940-977. August 25, 2017 http://www.repository.law. indiana.edu/ilj/vol86/iss3/5.

Pomorski, Stanisław. 1975. "American Common Law and the Principle Nullum Crimen Sine Lege". Warszawa: PWN.

Reinhart, Christopher. 2007. "Castle Doctrine and Self-defense", Connecticut General Assembly". Office of Legislative Research. 27 August 2017 https:// www.cga.ct.gov/2007/rpt/2007-r-0052.htm.

Sepko, Martyna. 2015. „Rozważania na temat propozycji rozszerzenia granic obrony koniecznej w projekcie poselskim z 19 stycznia 2015 r.”. Internetowy Przegląd Prawniczy TBPS UJ, 18(1) September 1, 2017 http://www.tbsp.wpia. uj.edu.pl/documents/4137545/d24eb2da-09ae-4708-b8e1-d4338c074306.

Simons, Kenneth W. 2008. „Self-Defense: Reasonable Beliefs or Reasonable Self-Control?”, New Criminal Law Review, 11(1): 51-90. 
Wright, Andrew P. 1997. "Resisting Unlawful Arrests: Inviting Anarchy or Protecting Individual Freedom?”, Drake Law Review 46(2):383-406. August 25, 2017 https://lawreviewdrake.files.wordpress.com/2016/09/wright.pdf.

Zoll, Andrzej. 2004. "Kodeks Karny. Komentarz, część ogólna”. Kraków: Zakamycze.

Zoll, Andrzej. 2007. „Kodeks Karny. Komentarz 2007”. Warszawa: Wolters Kluwer. 